\title{
ASSESSMENT OF IN VITRO DEVELOPMENTAL CAPACITY OF PORCINE NUCLEAR-TRANSFERRED EMBRYOS RECONSTITUTED WITH CUMULUS OOPHORUS CELLS UNDERGOING VITAL DIAGNOSTICS FOR APOPTOSIS DETECTION*
}

\author{
Marcin Samiec*, Maria Skrzyszowska \\ Department of Biotechnology of Animal Reproduction, \\ National Research Institute of Animal Production, 32-083 Balice n. Kraków, Poland \\ •Corresponding author: marcin.samiec@izoo.krakow.pl
}

\begin{abstract}
The objective of the current investigation was to extensively compare the in vitro developmental capabilities between cloned pig embryos reconstructed with the cell nuclei of either cumulus oophorus cells or adult dermal fibroblast cells that were both evaluated as non-apoptotic on the basis of YO-PRO-1- and Annexin V-eGFP-mediated vital analysis for programmed cell suicide. In Group I, the competences of nuclear-transferred (NT) embryos that were derived from non-apoptotic/non-necrotic (i.e., YO-PRO-1- and Annexin V-eGFP-negative) cumulus cells to complete their development to the morula and blastocyst stages were maintained at the proportions of $155 / 364$ $(42.6 \%)$ and 54/364 (14.8\%), respectively. In Group II, NT embryos that were reconstituted with non-apoptotic and/or non-necrotic adult cutaneous fibroblast cells developed to the morula and blastocyst stages at the rates of 207/358 (57.8\%) and 110/358 (30.7\%), respectively. Although the in vitro developmental potential of porcine $\mathrm{NT}$ embryos derived from non-apoptotic/non-necrotic cumulus cells was significantly lower $(\mathrm{P}<\mathbf{0 . 0 0 1})$ than that of NT embryos reconstructed with adult dermal fibroblast cells, the obtained morula/blastocyst formation rates turned out to be considerably higher as compared to the rates reported by other investigators. Altogether, to our knowledge, the comprehensive research aimed at the determination of preimplantation developmental outcomes of cloned pig embryos produced using nuclear donor somatic cells of different provenance (cumulus oophorus cells or adult cutaneous fibroblast cells) that were vitally diagnosed for the lack of proapoptotic transformations in their plasma membranes has not yet been accomplished.
\end{abstract}

Key words: pig, cumulus oophorus cell, adult dermal fibroblast cell, YO-PRO-1 fluorochrome, Annexin V-eGFP conjugate, apoptotic cell death, cloned embryo

*Source of research financing: This study was conducted as a part of both research project No. NR12 003606 and statutory activity No. 02-1.00.1, which were financed from 2009 to 2013 by the National Centre for Research and Development in Poland and from 2012 to 2014 by the Polish Ministry of Science and Higher Education, respectively. 
The efficiency of somatic cell cloning in pigs and other mammalian species is determined by many factors. One of the most important factors is morphological, ultrastructural, biochemical and biophysical quality of nuclear donor cells (Lee et al., 2003 a, b; Samiec and Skrzyszowska, 2012 a). Nevertheless, ultrastructural, biochemical and biophysical alterations that are one of the earliest symptoms of suicidal cell death (apoptosis) may be not reflected in the morphological transformations of somatic cells (Kues et al., 2002; Anger et al., 2003; Skrzyszowska et al., 2006).

Qualitative and quantitative evaluation of somatic cells based on the morphological criteria, which include above all: 1. cellular size/diameter ranging from 10 to $20 \mu \mathrm{m} ; 2$. spherical shape of the cell; 3. smooth (non-corrugated) and intact (blebbing-deprived) surface of plasma membrane; 4. lack of symptoms of cytolysis, and also 5. lack of degenerative changes in the cytoplasm involving either necrotic vacuolization and osmotic swelling or apoptotic diminution of the cytosolic volume as a result of both dehydration and gradual shrinkage of plasmalemma, may be insufficient for practical application in the cloning (Yin et al., 2002; Koo et al., 2004; Lee et al., 2003 a, 2005; Skrzyszowska et al., 2006). Biochemical, biophysical and ultrastructural changes that are one of the earliest prognostic indicators of programmed cell death (PCD) include the loss of phospholipid composition asymmetry and thereby the loss of anisotropy in the distribution of lipid molecules within the plasma membrane, which are both triggered by the externalization of phosphatidylserine (PS) residues onto the surface of plasmalemma (Fadok et al., 1992 a; Martin et al., 1995; Engeland et al., 2001). In turn, biochemical and ultrastructural changes that seem to be consistent with middle- to late-phase apoptotic symptoms include the appearance of the microchannels in the plasma membrane and megachannels in the semipermeable membranes of such intracellular compartments/organelles as mitochondria and endoplasmic reticulum (Estaquier et al., 1995; Idziorek et al., 1995; Skrzyszowska et al., 2006). These changes may not be accompanied by the morphological transformations of somatic cells involving superficial corrugation (retraction) and blebbing of plasmalemma associated with the shrinkage of the cytoplasm (Samiec and Skrzyszowska, 2012 a; Skrzyszowska et al., 2006). All the above-mentioned cytophysiological proapoptotic alterations can be detected by different fluorescent methods including either vital or non-vital diagnostics of the cells. One of the intra vitam diagnostic methods relies on the use of highly labile, yellowy-green DNA fluorochrome YO-PRO-1 that displays the ability to easily diffuse through the microchannels arising in the plasma membrane and the megachannels in the semipermeable membranes of intracellular compartments (Daly et al., 1997; Estaquier et al., 1996; Lincz, 1998; Samiec and Skrzyszowska, 2012 a; Skrzyszowska et al., 2005). The second method is focused on the confirmation of the exposure of the phosphatidylserine (PS) residues on the surface of plasmalemma, to which the moieties of the anti-coagulative, amphitropic, calcium-dependent and low molecular weight $(35.8 \mathrm{kDa})$ glycoprotein called Annexin $\mathrm{V}$ that is conjugated with the bioluminescent Aequorea victoria hydrozoan-derived fluorochrome protein, known as enhanced green fluorescent protein (eGFP), has high affinity (Fadok et al., 1992 b, 1993; Frasch et al., 2004). The YO-PRO-1- or Annexin V-eGFP-mediated vital ap- 
proach to qualitative and quantitative detection of proapoptotic alterations enables to estimate the percentage of poor-quality apoptotic and/or necrotic cells in relation to the total number of analysed cells originating from representative samples, without quantification of their early-apoptotic, late-apoptotic and/or necrotic cells (Samiec and Skrzyszowska, 2012 a; Skrzyszowska et al., 2006).

The objective of our current investigation was to comparatively examine the in vitro developmental outcomes of nuclear-transferred (NT) pig embryos that were derived from non-apoptotic/non-necrotic (i.e., YO-PRO-1-/Annexin V-eGFP-negative) cumulus oophorus cells and adult cutaneous fibroblast cells. Before their selection for somatic cell cloning, the morphological, biochemical, biophysical and ultrastructural quality of both types of porcine nuclear donor cells (cumulus cells and adult dermal fibroblast cells), which was based on the comprehensive detection of apoptotic cell death symptoms, had been evaluated.

\section{Material and methods}

\section{Collection and in vitro meiotic maturation of porcine oocytes}

Unless otherwise mentioned, all chemicals used in this study were purchased from Sigma-Aldrich Chemical Co. (St. Louis, MO, USA).

Slaughterhouse ovaries were collected from both prepubertal female pigs (gilts) and postpubertal female pigs (gilts and sows). Cumulus-oocyte complexes (COCs) were recovered by aspiration of follicular fluid from 2- to 6-mm antral ovarian follicles using an 18-gauge needle attached to a 10-mL disposable syringe. The COCs were collected into Tissue Culture Medium 199 (TCM 199-HEPES; Gibco BRL, Life Technologies Inc., Grand Island, NY, USA) that was buffered with $25 \mathrm{mM}$ 4-(2-hydroxyethyl)piperazine-1-ethanesulfonic acid (N-(2-hydroxyethyl) piperazine-N'-(2-ethanesulfonic acid); HEPES, $\mathrm{C}_{8} \mathrm{H}_{18} \mathrm{~N}_{2} \mathrm{O}_{4} \mathrm{~S}$ ) and supplemented with $5 \mathrm{IU} \mathrm{mL} \mathrm{mL}^{-1}$ heparin. The COCs, with evenly granulated ooplasm and several uniform layers of compact cumulus cells, were washed three times in TC 199-HEPES medium with the addition of $4 \mathrm{mg} \mathrm{mL}^{-1}$ bovine serum albumin (fraction V; BSA-V) and selected for in vitro maturation under atmospheric conditions. Immature COCs were transferred into the single wells of Nunclon polystyrene four-well multidishes (Nunclon $\Delta$ Surface; Nunc A/S, Nalge Nunc International, Thermo Fisher Scientific, Roskilde, Denmark) filled with $500 \mu \mathrm{L}$ of TC 199 maturation medium that had been previously overlaid with light mineral oil and equilibrated at $39^{\circ} \mathrm{C}$ in atmosphere of $5 \% \mathrm{CO}_{2}$ in air for 1 to $3 \mathrm{~h}$. The maturation medium was comprised of $25 \mathrm{mM}$ HEPES- and $26.2 \mathrm{mM}$ sodium bicarbonate-buffered Tissue Culture Medium 199 (Gibco BRL) and supplemented with 10\% porcine follicular fluid (pFF), $0.6 \mathrm{mM}$ $L$-cysteine, $10 \mathrm{ng} \mathrm{mL}^{-1}$ recombinant human epidermal growth factor (rhEGF), $1 \mathrm{mM}$ dibutyryl cyclic adenosine monophosphate (db-cAMP; bucladesine) and $0.1 \mathrm{IU} \mathrm{mL}^{-1}$ human menopausal gonadotropin (hMG). Approximately 50 to $60 \mathrm{COCs}$ were cultured in the db-cAMP- and hMG-supplemented medium for $20 \mathrm{~h}$ at $39^{\circ} \mathrm{C}$ in a $100 \%$ water-saturated atmosphere of $5 \% \mathrm{CO}_{2}$ and $95 \%$ air. The oocytes were then cultured 
for 22 to $24 \mathrm{~h}$ in fresh maturation medium that did not contain db-cAMP and hMG (Samiec and Skrzyszowska, 2010 a; Skrzyszowska et al., 2008).

After maturation, expanded cumulus oophorus cells and corona radiata cells were completely removed by vigorous pipetting of COCs in the presence of $0.5 \mathrm{mg} \mathrm{mL}^{-1}$ $\left(50 \mathrm{IU} \mathrm{mL}^{-1}\right.$ ) bovine testis-derived hyaluronidase in $500 \mu \mathrm{L}$ of HEPES-buffered TCM 199 for 1 to 2 min. In vitro-matured, metaphase II (MII)-stage oocytes, selected on the basis of accepted morphological criteria, and first of all with evenly granulated, dark cytoplasm and an intact plasma membrane, and with distinctly extruded first polar bodies (polocytes) provided a source of recipient cells for exogenous cell nuclei for the somatic cloning procedure (Samiec and Skrzyszowska, $2012 \mathrm{a}, \mathrm{b}$ ).

\section{Isolation of porcine cumulus oophorus cells}

The freshly collected cumulus cells were dissociated from expanded cumulus masses of in vitro-matured COCs by vortexing them for 1 to $2 \mathrm{~min}$ in TCM 199-HEPES supplemented with $0.5 \mathrm{mg} \mathrm{mL}^{-1}$ hyaluronidase and washing three times in the medium with addition of $4 \mathrm{mg} \mathrm{mL}^{-1}$ BSA-V (Samiec et al., 2003; Samiec and Skrzyszowska, 2010 b; Skrzyszowska et al., 2005).

\section{Isolation, in vitro culture and mitotic cycle synchronization of porcine fi- broblast cells}

Adult fibroblast cells were collected from an ear-skin biopsy obtained from a 8-month-old (postpubertal) female pig (sow). The subcutaneous and cutaneous tissue samples were cut into small pieces using a tissue chopper $(0.5 \mathrm{~mm})$. The resultant tissue explants were placed in a $12.5-\mathrm{cm}^{2}$ polystyrene BD Falcon cell culture flask (Becton Dickinson Co., Franklin Lakes, NJ, USA) filled with a small volume of Dulbecco's Modified Eagle's Medium (DMEM, Gibco Invitrogen Co., Paisley, Scotland, UK) to wet the bottom of the flask, but not enough volume to cause the tissue pieces to float. During the first 2 to 3 days of incubation, a few more drops of the medium were added every 2 to $3 \mathrm{~h}$, and more medium was added gradually when the pieces had firmly attached to the bottom of the culture flask. The cultures were replenished 2 to 3 times per week. Primary cultures of ear skin-derived fibroblast cells were grown in modified Dulbecco's Minimum Essential Medium that was formulated to contain high concentration of $D$-glucose $\left(4 \mathrm{mg} \mathrm{mL}^{-1}\right)$. This medium was supplemented with $10 \%$ heat-inactivated foetal bovine serum (FBS), $5 \mathrm{ng} \mathrm{mL}^{-1}$ recombinant human basic fibroblast growth factor (rh-bFGF), $2 \mathrm{mM} L$-glutamine ( $L$-Gln), $0.36 \mathrm{mM}$ sodium pyruvate, $1 \%$ antibiotic-antimycotic solution (AAS) and $2 \mathrm{mM}$ iso-nitrogenous nonessential amino acid (NEAA) solution based on Eagle's Minimum Essential Medium (MEM). After removal of the explants (Days 5 to 6), monolayers of fibroblast cells were detached from the bottom of the culture flask and disaggregated/digested into a single cell suspension using DMEM that was deprived of such cell chemoattractants as $10 \%$ FBS and supplemented with the cell detachment/digestion buffer consisting of $0.25 \%$ trypsin and $0.01 \%$ ethylenediaminetetraacetic acid (EDTA). The cells were subsequently cultured to total confluence and then passaged at least twice. The cells harvested from the flasks by trypsinization were washed in 10-mL manipulation medium (HEPES-buffered Tissue Culture Medium 199) enriched with 10\% FBS and 
centrifuged at $200 \times \mathrm{g}$ for $10 \mathrm{~min}$. The cell pellet was then suspended in FBS containing 9\% dimethyl sulfoxide (DMSO) before freezing in a Minicool freezer (Minicool 40 PC; Air Liquide, Bussy-Saint-Georges, France). The cryopreserved donor cells were thawed at $37^{\circ} \mathrm{C}$, and $200 \mu \mathrm{L}$ of FBS was added. The suspension was incubated at room temperature for $10 \mathrm{~min}$, and then $800 \mu \mathrm{L}$ of cell culture medium was added (Samiec and Skrzyszowska, 2010 b, 2012 a; Skrzyszowska et al., 2008).

Before their use for somatic cell nuclear transfer (SCNT), the frozen/thawed clonal cell lines (cell strains) of adult dermal fibroblasts were cultured in vitro to total confluence (in the medium supplemented with $10 \%$ FBS) to synchronize their mitotic cycle at the G1/G0 stages by initiating 24- to 48-h contact inhibition of their migration and proliferative growth (Samiec and Skrzyszowska, 2010 a; Samiec et al., 2012). After the cell cycle synchronization had been completed, the cultured clonal fibroblast cell lines (between passages 2 and 4) were trypsinized, followed by centrifugation at $300 \times \mathrm{g}$ for $5 \mathrm{~min}$. The supernatant was subsequently removed, and $50 \mu \mathrm{L}$ of the manipulation medium enriched with $4 \mathrm{mg} \mathrm{mL}^{-1} \mathrm{BSA}-\mathrm{V}$ was added (Samiec and Skrzyszowska, 2010 b).

\section{Preparation and subsequent analysis of nuclear donor cells for apoptosis Live-DNA or plasma membrane labelling of somatic cells}

To detect the early-phase and middle-to-late-phase apoptotic changes in the noncultured/freshly recovered cumulus cells (harvested by hyaluronidase-mediated digestion) and cultured sow ear skin-derived fibroblast cells (harvested by trypsinmediated digestion), a single nuclear donor cell suspension (adjusted to a density of $1 \times 10^{5}$ to $1 \times 10^{6}$ cells per $1 \mathrm{~mL}$ of medium) was subjected to two intra vitam tagging methods with the use of different diagnostic markers. In the first method, the cells, which had been previously suspended in $1000 \mu \mathrm{L}$ of TC 199-HEPES medium supplemented with $4 \mathrm{mg} \mathrm{mL} \mathrm{mL}^{-1} \mathrm{BSA}-\mathrm{V}$, were dyed with $1 \mu \mathrm{g} \mathrm{mL} \mathrm{m}^{-1}$ yellowy-green live-DNA fluorochrome YO-PRO-1 (Vybrant Apoptosis Assay Kit 4; Molecular Probes, Eugene, OR, USA) at a concentration of $100 \mu \mathrm{M}$ in DMSO solution (Idziorek et al., 1995; Samiec and Skrzyszowska, 2012 a). In the second method, the cells were labelled with the conjugate of Annexin V and eGFP protein (ApoAlert Annexin V-EGFP Apoptosis Kit; Clontech; Becton, Dickinson and Co., BD Biosciences, Palo Alto, CA, USA), which has a high affinity for PS residues exposed on the surface of the plasmalemma (Fadok et al., 1992 a; Martin et al., 1995; Skrzyszowska et al., 2006). The reactive mixture was comprised of $5 \mu \mathrm{L}$ of diagnostic conjugate at a concentration of $40 \mu \mathrm{g} \mathrm{mL}^{-1}$ in phosphate-buffered saline (PBS) solution and $200 \mu \mathrm{L}$ of $10 \%$ FBS-enriched binding buffer, which chelates a surplus of Annexin $\mathrm{V}$-eGFP reagent molecules preferentially linked to the negatively charged PS moieties. The reactive buffer solution $(\mathrm{pH}=7.4)$ consisted of $10 \mathrm{mM}$ HEPES sodium salt (HEPES/NaOH; $\mathrm{C}_{8} \mathrm{H}_{17} \mathrm{~N}_{2} \mathrm{NaO}_{4} \mathrm{~S}$ ), $140 \mathrm{mM} \mathrm{NaCl}, 2 \mathrm{mM} \mathrm{CaCl}_{2}, 5 \mathrm{mM} \mathrm{KCl}$ and $1 \mathrm{mM} \mathrm{MgCl}_{2}$. After a 15- to 20-min incubation of the somatic cells in one of the two diagnostic solutions, any proapoptotic alterations in the plasma membranes were assessed in the dark on an epi-fluorescent microscope (Olympus IMT-2, Tokyo, Japan). The nuclear donor cells were evaluated for apoptosis after a short (approximately 10to 20-sec) excitation of the somatic cell-descended DNA and YO-PRO-1 complexes 
or PS and Annexin V-eGFP complexes with blue light (at an excitation/absorption maximum wavelength of $\lambda_{\max }=488 \mathrm{~nm}$ ). Approximately $50 \mathrm{YO}-\mathrm{PRO}-1$ - or Annexin V-eGFP-tagged representative (random) cell samples ranging from $0.5 \times 10^{3}$ to $1 \times 10^{3}$ cells per sample were collected from the populations of freshly-isolated cumulus cells and cultured/trypsinized adult dermal fibroblast cells whose mitotic cell cycle had been synchronized at the G1/G0 phases by the contact inhibition of their migration and proliferative growth. The cells that did not emit the yellowy-green YO-PRO-1-derived or green eGFP-derived fluorescence under the emission maximum wavelength $\lambda_{\max }=530 \mathrm{~nm}$ were classified as non-apoptotic/non-necrotic and used for the SCNT procedure (Samiec and Skrzyszowska, 2012 a; Skrzyszowska and Samiec, 2005, 2008; Skrzyszowska et al., 2006, 2007).

\section{Production of porcine nuclear-transferred embryos}

Cumulus-denuded in vitro-matured oocytes were incubated in the maturation medium supplemented with $0.4 \mu \mathrm{g} \mathrm{mL}^{-1}$ demecolcine (DMCC; colcemid, N-deacetyl$\mathrm{N}$-methylcolchicine) and $0.05 \mathrm{M}$ sucrose for $1 \mathrm{~h}$ at $39^{\circ} \mathrm{C}$. Afterwards, the treated oocytes were transferred into a glass micromanipulation chamber filled with TCM 199 with addition of $4 \mathrm{mg} \mathrm{mL}^{-1} \mathrm{BSA}-\mathrm{V}, 5 \mu \mathrm{g} \mathrm{mL} \mathrm{m}^{-1}$ cytochalasin B (CB) and $0.4 \mu \mathrm{g}$ $\mathrm{mL}^{-1}$ DMCC. Maternal chromosomes (metaphase plates), which had been allocated into chemically induced protrusion of plasma membrane, were removed microsurgically (Yin et al., 2002). Enucleation was accomplished by gently aspirating the ooplasmic cone, which contained condensed chromosome cluster, with the aid of a bevelled micropipette of 20 - to $25-\mu \mathrm{m}$ external diameter. Following enucleation, the resulting cytoplasts (ooplasts) were washed extensively in HEPES-buffered TCM 199/BSA-V and held in this CB- and DMCC-free medium until either intracytoplasmic microinjection of live-membrane cellular structures containing cell nuclei (i.e., karyoplasts) that had been isolated from whole nuclear donor cells or subzonal microinjection of intact nuclear donor cells were performed. Reconstruction of enucleated oocytes (ooplasts) was achieved by intracytoplasmic microinjection of cumulus cell-derived karyoplasts (donor nuclei surrounded with perikaryon, i.e., very thin perinuclear cytoplasmic layer/ring; Group I) or by electrofusion of whole adult dermal fibroblast cells with ooplasts (Group II). Nuclear donor cells were selected under Nomarski prism-based differential interference contrast (DIC) optics according to their size and shape. For cumulus oophorus cells, only the spherical-shaped cells with a smooth, intact plasmalemma surface were chosen for preparation (microsurgical isolation) of karyoplasts intended to be injected directly into the cytoplasm of enucleated oocytes. By using an microinjection pipette, the sharp, bevelled tip of which had an external diameter about half smaller than the diameter of the selected cells, the cumulus cell plasma membranes were broken by gentle, repeated aspiration of the entire cells into and out of the pipette. As a result, cytolysis was mechanically induced and the karyoplasts were released from the lysed cells. Subsequently, the microinjection pipette was introduced manually through the zona pellucida (using the same slit as was made during enucleation) and up to halfway into the ooplasm of each cytoplast and the tiny karyoplast was quickly deposited with the cytoplasm (Samiec et al., 2003; Samiec and Skrzyszowska, 2005 
a, b, 2010 b; Skrzyszowska et al., 2005). The reconstructed oocytes (i.e., clonal cybrids) were incubated in North Carolina State University-23 (NCSU-23) medium supplemented with $4 \mathrm{mg} \mathrm{mL}^{-1} \mathrm{BSA}-\mathrm{V}$ at $39^{\circ} \mathrm{C}$ in a $100 \%$ humidified atmosphere of $5 \% \mathrm{CO}_{2}$ in air for $1 \mathrm{~h}$ before activation. Reconstructed oocytes were equilibrated in $500 \mu \mathrm{L}$ of electroporation medium for 1 to $2 \mathrm{~min}$ at $39^{\circ} \mathrm{C}$ and then transferred to a BTX electroactivation chamber (BTX Model 450; Harvard Apparatus, Holliston, MA, USA), which was positioned between two parallel wire electrodes $0.5 \mathrm{~mm}$ apart. The chamber was overlaid with 0.5 to $1 \mathrm{~mL}$ of the same medium. Activation of clonal cybrids was induced with two successive DC pulses of $1.2 \mathrm{kV} \mathrm{cm}^{-1}$ for $60 \mu \mathrm{s}$ each, delivered by a BTX Electro Cell Manipulator 200 (BTX ECM Model 200; Biotechnologies \& Experimental Research, Inc., San Diego, CA, USA). Immediately after electroactivation, nuclear-transferred oocytes were left once more in the electroporation medium for $5 \mathrm{~min}$ at $39^{\circ} \mathrm{C}$, before being transferred to the NCSU-23/ BSA-V medium supplemented with $5 \mu \mathrm{g} \mathrm{mL}^{-1} \mathrm{CB}$ for $2 \mathrm{~h}$ (Samiec and Skrzyszowska, $2010 \mathrm{~b}$ ). The electroporation medium was isotonic dielectric solution consisting of $0.3 \mathrm{M} \mathrm{D}$-mannitol, $0.05 \mathrm{mM} \mathrm{CaCl}_{2}, 0.1 \mathrm{mM} \mathrm{MgSO}_{4}$, and $0.2 \mathrm{mg} \mathrm{mL}^{-1}$ fatty acid-free BSA (FAF-BSA).

For fibroblast cells, single nuclear donor cells were inserted subzonally into the perivitelline space of previously enucleated oocytes. The resulting whole somatic cellooplast couplets were transferred to a fusion/activation chamber filled with the electroporation medium, which was comprised of $0.3 \mathrm{M}$ D-mannitol enriched with $1.0 \mathrm{mM}$ $\mathrm{CaCl}_{2}, 0.1 \mathrm{mM} \mathrm{MgSO}_{4}$ and $0.2 \mathrm{mg} \mathrm{mL}^{-1} \mathrm{FAF}-\mathrm{BSA}$. Fibroblast cell-ooplast complexes were simultaneously fused and activated with two consecutive DC pulses of $1.2 \mathrm{kV}$ $\mathrm{cm}^{-1}$ for $60 \mu \mathrm{s}$ each (Samiec and Skrzyszowska, 2012 b; Samiec et al., 2012).

\section{In vitro culture of reconstructed embryos}

Cloned embryos were cultured in 50- $\mu$ L droplets of NCSU-23 medium supplemented with $4 \mathrm{mg} \mathrm{mL}^{-1}$ BSA-V, 1\% MEM-based non-essential amino acid solution (MEM-NEAA) and 2\% MEM-based essential amino acid solution (MEM-EAA). The number of embryos per droplet of culture medium that had been overlaid with light mineral oil ranged from 20 to 30 . After 72 to $96 \mathrm{~h}$ of in vitro culture, the cleaved embryos were placed into a $50-\mu \mathrm{L}$ drop of NCSU-23/BSA-V/MEM-NEAA/MEMEAA medium enriched with 10\% FBS for an additional $72 \mathrm{~h}$. The nuclear-transferred embryos were incubated at $39^{\circ} \mathrm{C}$, in a $100 \%$ water-saturated atmosphere of $5 \% \mathrm{CO}_{2}$ and $95 \%$ air. At the end of the in vitro culture period (Days 6 to 7 ), the embryos were evaluated morphologically for morula and blastocyst formation rates (Samiec and Skrzyszowska, 2010 b, 2012 a; Skrzyszowska et al., 2008).

\section{Experimental design}

In the first series of experiments, the rates of apoptotic and/or necrotic cells (i.e., apoptotic/necrotic index) in the subpopulations of cumulus oophorus cells and adult ear skin-derived fibroblast cells were estimated by their vital analysis relying on the fluorescent labelling with either YO-PRO-1 DNA stain or Annexin V-eGFP conjugate.

In the second series of experiments, the in vitro developmental competences were investigated among porcine nuclear-transferred (NT) embryos reconstructed with 
cumulus oophorus cells or adult cutaneous fibroblast cells that had been analysed for apoptosis incidence through the vital fluorescent tagging.

In the third series of experiments, abilities of cloned embryos not only to divide, but also to form the morulae and blastocysts were evaluated following reconstruction of enucleated pig oocytes with the cell nuclei of YO-PRO-1-/Annexin V-eGFP-negative and randomly selected cumulus oophorus cells or adult dermal fibroblast cells.

\section{Statistical analysis}

The chi-square test was applied to compare the proportions of apoptotic/necrotic cells between the subpopulations of freshly retrieved cumulus cells and contactinhibited adult cutaneous fibroblast cells. This test was also used for prediction of the statistical variations in the frequencies of successfully reconstructed oocytes, the frequencies of dividing embryos and the frequencies of embryos at the morula and blastocyst stages between different experimental groups encompassing either the nuclear donor cell type or the presence/lack of YO-PRO-1-/Annexin V-eGFP-based pre-selection of non-apoptotic and non-necrotic somatic cells before their use for the cloning procedure.

\section{Results}

The use of DNA and plasmalemma fluorescent indicators for intra vitam detection of apoptosis in porcine cumulus and adult dermal fibroblast cells before somatic cell nuclear transfer

YO-PRO-1-mediated fluorescent analysis of freshly isolated cumulus cells or cultured (contact-inhibited) sow cutaneous fibroblast cells revealed that a relatively high proportion of nuclear donor cells displayed ultrastructural proapoptotic changes. Additionally, the morphological features of these cells suggested that they were undergoing middle-to-late-phase apoptosis and/or necrosis. The percentages of apoptotic and/or necrotic (YO-PRO-1-positive) cells with advanced morphological transformations ranged from approximately 10 to $15 \%$ and from approximately 20 to $25 \%$ per each of 50 analysed random samples of cumulus cells and contact-inhibited adult skin-derived fibroblast cells, respectively (Table 1). On the contrary, cells that were evaluated as morphologically normal did not emit yellowy-green YO-PRO1-derived fluorescence. These data suggest that the YO-PRO-1-negative cells are non-apoptotic/non-necrotic, or, alternatively, that the YO-PRO-1 dye may be not able to detect the early phases of apoptosis, which are typically not accompanied by morphological changes of the somatic cells.

In turn, fluorescent analysis of Annexin V-eGFP-tagged cumulus cells and contact-inhibited adult dermal fibroblast cells revealed that the proportions of the cells with middle- to late-phase apoptotic and/or necrotic changes decrease considerably compared to those of the YO-PRO-1-labelled cumulus cells, but they increase considerably compared to those of the YO-PRO-1-stained fibroblast cells. The percentages of middle- to late-phase apoptotic and necrotic cells with advanced biochemi- 
cal, biophysical, ultrastructural and morphological transformations did not exceed approximately $5 \%$ and $30 \%$ per each of 50 diagnosed random samples of cumulus cells and contact-inhibited adult cutaneous fibroblast cells, respectively (Table 2). Moreover, the Annexin V-eGFP-based analysis confirmed the extremely low rate (ranging from 0 to $3 \%$ ) of the cells with normal plasmalemma ultrastructure and morphology that emitted the green eGFP-derived bioluminescence. These findings indicate that such Annexin V-eGFP-positive cells are early- to middle-phase apoptotic, i.e., that apoptosis process in these cells did not pass through the irreversibility check-point at the middle phase.

Table 1. Effect of the cell cycle synchronization strategy on the frequency of apoptosis/necrosis occurrence among two subpopulations of porcine somatic cells vitally analysed using DNA fluorochrome YO-PRO-1

\begin{tabular}{l|c}
\hline $\begin{array}{c}\text { Type of nuclear donor cells undergoing YO-PRO-1- } \\
\text { mediated analysis }\end{array}$ & $\begin{array}{c}\text { Percentage of middle- to late-phase } \\
\text { apoptotic/necrotic (YO-PRO-1-positive) } \\
\text { cells }\end{array}$ \\
\hline Freshly recovered (non-cultured) cumulus cells & $10-15 \% \mathrm{~A}$ \\
Cultured (contact-inhibited) adult dermal fibroblast cells & $20-25 \% \mathrm{~B}$ \\
\hline
\end{tabular}

A, B - values with different letters within the same column differ significantly $(\mathrm{P}<0.01$, chi-square test). Number of replicates $=50$.

Table 2. Effect of the cell cycle synchronization strategy on the frequency of apoptosis/necrosis occurrence among two subpopulations of porcine somatic cells vitally analysed using plasmalemma fluorescent marker Annexin V-eGFP

\begin{tabular}{l|c}
\hline $\begin{array}{c}\text { Type of nuclear donor cells undergoing } \\
\text { Annexin V-eGFP-mediated analysis }\end{array}$ & $\begin{array}{c}\text { Percentage of } \\
\text { middle- to late-phase apoptotic/necrotic } \\
\text { (Annexin V-eGFP-positive) cells }\end{array}$ \\
\hline $\begin{array}{l}\text { Freshly recovered (non-cultured) cumulus cells } \\
\text { Cultured (contact-inhibited) adult dermal fibroblast cells }\end{array}$ & $5 \% \mathrm{~A}$ \\
\hline
\end{tabular}

A, B - values with different letters within the same column vary significantly $(\mathrm{P}<0.001$, chi-square test). Number of replicates $=50$.

\section{Generation of cloned pig embryos descended from non-apoptotic and/or non-necrotic cumulus cell nuclei or adult dermal fibroblast cell nuclei}

In Group I (Table 3), a total of 364/412 (88.3\%) enucleated oocytes were successfully injected with karyoplasts isolated from cumulus cells, which had been previously analysed intra vitam for apoptosis/necrosis (i.e., classified as non-apoptotic and/or non-necrotic). Following activation, 364/412 (88.3\%) reconstituted oocytes were selected for in vitro culture. Out of 364 cultured NT embryos, $202(55.5 \%)$ did not fail to divide. The rates of nuclear-transferred embryos that developed to the morula and blastocyst stages were 155/364 (42.6\%) and 54/364 (14.8\%), respectively.

In Group II (Table 3), a total of 387 enucleated oocytes underwent electrofusion with non-apoptotic/non-necrotic adult dermal fibroblast cells that had been previously contact-inhibited under $100 \%$ confluency conditions. Out of 387 simultaneously fused and electrically activated oocytes, $358(92.5 \%)$ were classified for in 
vitro culture. From among 358 cultured NT embryos, 261 (72.9\%) were cleaved. The developmental capabilities of cloned embryos that reached the morula and blastocyst stages remained at the levels of $207 / 358$ (57.8\%) and 110/358 (30.7\%), respectively.

Table 3. Comparison of the in vitro developmental outcomes between nuclear-transferred pig embryos reconstituted with freshly collected cumulus cells and contact-inhibited adult dermal fibroblast cells, both not displaying proapoptotic and/or pronecrotic symptoms

\begin{tabular}{|c|c|c|c|c|c|}
\hline \multirow[b]{2}{*}{$\begin{array}{l}\text { Type of non-apoptotic/ non- } \\
\text { necrotic nuclear donor cells }\end{array}$} & \multicolumn{3}{|c|}{ Number of oocytes/embryos } & \multicolumn{2}{|c|}{ Development to } \\
\hline & $\begin{array}{c}\text { reconstructed } \\
\text { (microinjected* } \\
\text { or electrofused**) }\end{array}$ & $\begin{array}{l}\text { cultured } \\
(\%)\end{array}$ & $\begin{array}{l}\text { cleaved } \\
(\%)\end{array}$ & $\begin{array}{l}\text { morulae } \\
(\%)\end{array}$ & $\begin{array}{c}\text { blastocysts } \\
(\%)\end{array}$ \\
\hline $\begin{array}{l}\text { Freshly recovered } \\
\text { (non-cultured) cumulus cells } \\
\text { [Group I] }\end{array}$ & $412 *$ & $\begin{array}{l}364 / 412 \\
(88.3) \mathrm{a}\end{array}$ & $\begin{array}{l}202 / 364 \\
(55.5) \mathrm{A}\end{array}$ & $\begin{array}{l}155 / 364 \\
(42.6) \mathrm{A}\end{array}$ & $\begin{array}{r}54 / 364 \\
(14.8) \mathrm{A}\end{array}$ \\
\hline $\begin{array}{l}\text { Cultured (contact-inhibited) } \\
\text { adult dermal fibroblast cells } \\
\text { [Group II] }\end{array}$ & $387 * *$ & $\begin{array}{l}358 / 387 \\
(92.5) \mathrm{a}\end{array}$ & $\begin{array}{l}261 / 358 \\
(72.9) \mathrm{B}\end{array}$ & $\begin{array}{l}207 / 358 \\
(57.8) \mathrm{B}\end{array}$ & $\begin{array}{l}110 / 358 \\
(30.7) \mathrm{B}\end{array}$ \\
\hline
\end{tabular}

a, a - values with identical letters within the same column do not differ significantly $(\mathrm{P} \geq 0.05$, chi-square test). Number of replicates $\geq 10$.

A, B - values with different letters within the same column vary significantly $(\mathrm{P}<0.001$, chi-square test $)$. Number of replicates $\geq 10$.

Table 4. Effect of YO-PRO-1- and Annexin V-eGFP-based pre-selection of cumulus oophorus cells on the in vitro developmental potential of nuclear-transferred pig embryos

\begin{tabular}{|c|c|c|c|c|c|}
\hline \multirow{2}{*}{$\begin{array}{c}\text { YO-PRO-1- and } \\
\text { Annexin } \\
\text { V-eGFP- } \\
\text {-mediated } \\
\text { pre-selection } \\
\text { of non-apoptotic } \\
\text { and non-necrotic } \\
\text { nuclear donor } \\
\text { cells } \\
\end{array}$} & \multicolumn{3}{|c|}{ Number of oocytes/embryos } & \multicolumn{2}{|c|}{ Development to } \\
\hline & enucleated & $\begin{array}{c}\text { microinjected } \\
(\%)\end{array}$ & $\begin{array}{c}\text { cleaved } \\
(\%)\end{array}$ & $\begin{array}{c}\text { morulae } \\
(\%)\end{array}$ & $\begin{array}{c}\text { blastocysts } \\
(\%)\end{array}$ \\
\hline+ & 412 & $\begin{array}{l}364 / 412 \\
(88.3) \mathrm{a}\end{array}$ & $\begin{array}{l}202 / 364 \\
\text { (55.5) A }\end{array}$ & $\begin{array}{l}155 / 364 \\
(42.6) \mathrm{C}\end{array}$ & $\begin{array}{c}54 / 364 \\
(14.8) \mathrm{A}\end{array}$ \\
\hline- & 377 & $\begin{array}{l}339 / 377 \\
(89.9) \mathrm{a}\end{array}$ & $\begin{array}{l}150 / 339 \\
(44.2) \mathrm{B}\end{array}$ & $\begin{array}{c}98 / 339 \\
(28.9) \mathrm{D}\end{array}$ & $\begin{array}{l}12 / 339 \\
(3.5) \mathrm{B}\end{array}$ \\
\hline
\end{tabular}

a, a - values with identical letters within the same column do not differ significantly $(\mathrm{P} \geq 0.05$, chi-square test). Number of replicates $\geq 10$.

A, B - values with different letters within the same column vary significantly ( $\mathrm{P}<0.01$, chi-square test). Number of replicates $\geq 10$.

C, D - values with different letters within the same column differ significantly $(\mathrm{P}<0.001$, chi-square test $)$. Number of replicates $\geq 10$.

As a next step, the rates of successful reconstruction of enucleated oocytes (by intraooplasmic donor cell nucleus microinjection or somatic cell-ooplast couplet electrofusion) and the in vitro developmental outcomes were assessed among nuclear-transferred pig embryos descended from YO-PRO-1-/Annexin V-eGFP-negative 
and randomly selected cumulus oophorus cells or adult cutaneous fibroblast cells (Tables 4 and 5). The proportions of enucleated oocytes that were effectively microinjected with karyoplasts isolated from cumulus cells or electrofused with adult dermal fibroblast cells did not vary significantly whether YO-PRO-1-/Annexin VeGFP-based pre-selection was carried out or not. Nevertheless, the cleavage division rates, morula and blastocyst yields trended significantly upwards for cloned embryos reconstituted with either YO-PRO-1- and Annexin V-eGFP-negative cumulus cell nuclei or adult cutaneous fibroblast cell nuclei as compared to those generated using both types of these nuclear donor cells that were not subjected to the YO-PRO-1- and Annexin V-eGFP-mediated pre-selection.

Table 5. Effect of YO-PRO-1- and Annexin V-eGFP-based pre-selection of adult cutaneous fibroblast cells on the in vitro developmental potential of nuclear-transferred pig embryos

\begin{tabular}{|c|c|c|c|c|c|}
\hline \multirow{2}{*}{$\begin{array}{c}\text { YO-PRO-1- and } \\
\text { Annexin } \\
\text { V-eGFP-mediated } \\
\text { pre-selection } \\
\text { of non-apoptotic } \\
\text { and non-necrotic } \\
\text { nuclear donor } \\
\text { cells }\end{array}$} & \multicolumn{3}{|c|}{ Number of oocytes/embryos } & \multicolumn{2}{|c|}{ Development to } \\
\hline & enucleated & $\begin{array}{c}\text { electrofused } \\
(\%)\end{array}$ & $\begin{array}{c}\text { cleaved } \\
(\%)\end{array}$ & $\begin{array}{c}\text { morulae } \\
(\%)\end{array}$ & $\begin{array}{c}\text { blastocysts } \\
(\%)\end{array}$ \\
\hline+ & 387 & $\begin{array}{l}358 / 387 \\
(92.5) \mathrm{a}\end{array}$ & $\begin{array}{l}261 / 358 \\
(72.9) \mathrm{a}\end{array}$ & $\begin{array}{l}207 / 358 \\
(57.8) a\end{array}$ & $\begin{array}{l}110 / 358 \\
(30.7) \mathrm{A}\end{array}$ \\
\hline- & 343 & $\begin{array}{r}321 / 343 \\
(93.6) \mathrm{a}\end{array}$ & $\begin{array}{l}201 / 321 \\
(62.6) \mathrm{b}\end{array}$ & $\begin{array}{l}153 / 321 \\
(47.7) \mathrm{b}\end{array}$ & $\begin{array}{c}61 / 321 \\
(19.0) \mathrm{B}\end{array}$ \\
\hline
\end{tabular}

a, a - values with identical letters within the same column do not vary significantly ( $\mathrm{P} \geq 0.05$, chi-square test). Number of replicates $\geq 9$.

$\mathrm{a}, \mathrm{b}$ - values with different letters within the same column differ significantly $(\mathrm{P}<0.05$, chi-square test). Number of replicates $\geq 9$.

A, B - values with different letters within the same column vary significantly $(\mathrm{P}<0.01$, chi-square test). Number of replicates $\geq 9$.

\section{Discussion}

The type, origin, cell cycle stage and structure-functional (i.e., morphological, biochemical and biophysical) quality of nuclear donor somatic cells are one of the most important factors affecting the effectiveness of cloning technique in pigs (Yin et al., 2002; Lee et al., 2003 a, b, 2005; Samiec and Skrzyszowska, 2010 b). Generally, in our investigation, the vital diagnostics of porcine cumulus oophorus cells and adult dermal fibroblast cells with the use of fluorescent markers such as YO-PRO-1 and Annexin V-eGFP did not reveal the presence of the early-apoptotic symptoms among the subpopulations of morphologically normal cells that provided the desirable source of nuclear donor cells for somatic cell cloning. These cells usually did not emit the bright green bioluminescence after the blue light-mediated excitation of the YO-PRO-1-nuclear DNA or Annexin V-eGFP-PS residue complexes (Samiec and Skrzyszowska, 2012 a; Skrzyszowska et al., 2005, 2006, 2007; Skrzyszowska and Samiec, 2005, 2008). Nonetheless, there was noticed a negligible percentage 
(not exceeding 3\%) of the early- to middle-phase apoptotic cells that exhibited the ability to be labelled with the Annexin V conjugated with eGFP fluorochromoprotein. Simultaneously, the ultrastructural and morphological transformations did not occur in their plasma membranes. Such fractions of morphologically normal cells that were classified as Annexin V-eGFP-positive were not considered to be suitable source of nuclear donors for our cloning experiments.

The present study has shown that morphological criteria, most frequently applied to estimation of the cellular viability, turn out to be insufficient selection factors for the qualitative and quantitative evaluation of nuclear donor cells before their use for the somatic cell cloning. The basic premise underlying this thesis is based on the findings that indicate the improved developmental capability of porcine NT embryos to reach the morula and blastocyst stages following reconstruction of enucleated oocytes with the cell nuclei of YO-PRO-1-/Annexin V-eGFP-negative cumulus oophorus cells (morula, 43\%; blastocyst, 15\%; Table 4) or adult cutaneous fibroblast cells (morula, 58\%; blastocyst, 31\%; Table 5) as compared to their reconstruction with the cell nuclei of randomly selected somatic cells (morula, 29\% or 48\%; blastocyst, $4 \%$ or $19 \%$, respectively).

So far, not many studies have compared the cloning competence of different types of nuclear donor cells for directing the mammalian embryo development to blastocyst stage. It has been demonstrated that bovine cloned embryos reconstructed with cell nuclei of serum-starved or non-starved cumulus cells or ear skin-derived fibroblast cells formed blastocysts at a higher rate than those derived from enucleated oocytes receiving the cell nuclei from uterine or oviductal epithelial cells (Cho et al., 2002). In turn, Wakayama and co-workers (1998) have demonstrated the decrease in developmental potential for murine NT embryos reconstituted with mature Sertoli cell- or neuronal cell-descended karyoplasts compared to that for cloned embryos generated using cumulus cell-descended karyoplasts. In contrast to foetal fibroblasts (Boquest et al., 2002; De Sousa et al., 2002; Hyun et al., 2003; Ramsoondar et al., 2003) or adult ear skin-derived fibroblasts (Bondioli et al., 2001; Park et al., 2002; Lee et al., 2003 a) that were most frequently used for the somatic cell cloning in pigs, the non-cultured (freshly recovered) cumulus cells were only sporadically the source of nuclear donors, although their mitotic cell cycle is physiologically synchronized at the G0/G1 phases as has been shown by Schuetz et al. (1996) and Wakayama et al. (1998) in mice. Relatively low rate of blastocyst formation and no offspring have been obtained from porcine NT embryos reconstructed with cumulus cells. This failure in the ability of cumulus cell nuclei for both complete epigenetic reprogramming and supporting the development of cloned embryos up to term can result from the fact that the mitotic cycle of cumulus cells, which have been freshly isolated from in vitro- or in vivo-matured (postovulatory) follicular cell-oocyte complexes, may be irreversibly blocked at the G0/G1 stages of interphasic period (Samiec, $2005 \mathrm{a}, \mathrm{b}$; Samiec and Skrzyszowska, $2011 \mathrm{a}, \mathrm{b}$ ). This permanent inhibition of division cell cycle can be induced by advanced processes of mucification (i.e., accumulation of hyaluronic acid and other glycosaminoglycans) within the intercellular spaces between the cells of cumulus oophorus and corona radiata (Schuetz et al., 1996; Wakayama et al., 1998; Samiec, 2004; Samiec and Skrzyszowska, 2005 a, b). In consequence, the 
porcine cumulus cells that had been subjected to only morphological evaluation prior to their use for the SCNT procedure can undergo middle-apoptotic biochemical and biophysical changes, which are linked with the passing through the irreversibility check-point of suicidal cell death. For this reason, these presumptive proapoptotic symptoms could prevent the cumulus cell nuclei from supporting the development of the majority of cloned embryos to blastocyst stage. The developmental competences to blastocyst stage of nuclear-transferred embryos reconstituted with cumulus cells, which were not analysed vitally for apoptosis with the use of either YO-PRO-1 fluorochrome or Annexin V-eGFP conjugate, were maintained at the very low level and ranged from approximately $0.5 \%$ to $7.0 \%$ (Uhm et al., 2000; De Sousa et al., 2002, Yin et al., 2002; Samiec et al., 2003; Lee et al., 2003 b). In our present study, the rate of cloned blastocysts generated from abattoir-derived oocytes receiving the nuclear genome of non-apoptotic/non-necrotic (i.e., YO-PRO-1- and Annexin V-eGFP-negative) cumulus cells was considerably higher (approximately 15\%) as compared to the rates reported by the above-mentioned investigators.

Similar to our previous study (Samiec and Skrzyszowska, 2010 b), in the current investigation, the capability of cloned pig embryos reconstructed with the cell nuclei of non-apoptotic/non-necrotic contact-inhibited adult cutaneous fibroblasts to complete their development to the blastocyst stage was significantly higher than the capability of embryos derived from the cell nuclei of freshly retrieved cumulus cells (almost $33.5 \%$ vs. $19.5 \%$ and $31 \%$ vs. $15 \%$, respectively). Alternatively to the results of our experiments, in the study by Lee et al. (2003 b), although the cultured adult dermal fibroblast cells had a slightly higher cloning competence (approximately 8\% blastocysts) compared to the competence of cultured cumulus cells (approximately $6 \%$ blastocysts), the differences between these two nuclear donor cell groups were not statistically significant. Nevertheless, we obtained a considerably higher percentage of blastocysts originating from nuclear-transferred embryos reconstituted with either adult ear skin-derived fibroblast cells or cumulus cells (nearly $31 \%$ and $15 \%$, respectively). But, the primary difference between our present study and the study by Lee et al. (2003 b) is that we have accomplished the intra vitam YO-PRO-1- and Annexin V-eGFP-mediated tagging of cumulus and adult dermal fibroblast cells to reveal the presence of middle- to late-phase apoptotic alterations in their plasma membranes before the cells were used as donor nuclei for the somatic cell cloning. Moreover, the possible explanation of lower cavitation rates in the study by Lee et al. (2003 b) may be that in contrast to our study, in which non-cultured cumulus cells or cultured (100\%-confluent) adult dermal fibroblast cells undergoing 1-2-Day contact inhibition of their migration and proliferative growth provided a source of nuclear donor cells, Lee and co-workers (2003 b) applied 3-5-Day serum starvation to synchronize the mitotic cycle of in vitro cultured somatic cells at the G0/G1 phases. Such long-term trophic deprivation of the clonal cell lines could give rise to enhancement of apoptosis incidence, promotion of advanced epigenetic alterations (e.g., DNA methylation, histone deacetylation), onset and/or progression of mutagen-induced chromosomal abnormalities, decline of telomerase activity and acceleration of telomere attrition, subsequent potentiation of replicative senescence, strengthening of cytophysiological ageing and thereby decrease of cellular survival 
rates and proliferative activities (Kues et al., 2002; Samiec, 2004, 2005 a, b; Jang et al., 2004; Jiang et al., 2004; Samiec and Skrzyszowska, 2005b, 2011 a, b).

Cumulatively, the in vitro developmental capacity of cloned pig embryos reconstructed with non-apoptotic and/or non-necrotic freshly isolated cumulus oophorus cells to reach the morula and blastocyst stages turned out to be considerably lower than the developmental capacity of embryos reconstructed with non-apoptotic/nonnecrotic cultured adult dermal fibroblast cells. To our knowledge, the comparative study of preimplantation development between porcine nuclear-transferred embryos derived from YO-PRO-1- and Annexin V-eGFP-negative cumulus cells and those derived from their adult cutaneous fibroblast cell counterparts was carried out for the first time.

\section{References}

Anger M., Kues W.A., Klima J., Mielenz M., Kubelka M., Motlik J., Esner M., D v or a k P., C a rnwarth J.W., N i e m a n n H. (2003). Cell cycle dependent expression of Plk1 in synchronized porcine fetal fibroblasts. Mol. Reprod. Dev., 65: 245-253.

Bondioli K., Ramsoondar J., Williams B., Costa C., Fodor W. (2001). Cloned pigs generated from cultured skin fibroblasts derived from a H-transferase transgenic boar. Mol. Reprod. Dev., 60: 189-195.

Boquest A.C., Grupen C.G., Harrison S.J., McIlfatrick S.M., Ashman R.J., d'A p i c e A.J.F., N ottl e M.B. (2002). Production of cloned pigs from cultured fetal fibroblast cells. Biol. Reprod., 66: 1283-1287.

Cho J.K., Lee B.C., Park J.I., Lim J.M., Shin S.J., Kim K.Y., Lee B.D., Hwang W.S. (2002). Development of bovine oocytes reconstructed with different donor somatic cells with or without serum starvation. Theriogenology, 57: 1819-1828.

D a l y J.M., J a n n o t C.B., B e e r l i R.R., G r a u s - P or t a D., M a u r e r F.G., H y n e s N.E. (1997). New differentiation factor induces ErbB2 down-regulation and apoptosis of ErbB2-overexpressing breast tumor cells. Cancer Res., 57: 3804-3811.

De Sousa P., Dobrinsky J.R., Zhu J., Archibald A.L., A inslie A., Bosma W., Bowering J., Bracken J., Ferrier P.M., Fletcher J., Gasparrini B., Harkness L., Johnston P., Ritchie M., Ritchie W.A., Travers A., Albertini D., Dinnyes A., King T.J., Wilmut I. (2002). Somatic cell nuclear transfer in the pig: control of pronuclear formation and integration with improved methods for activation and maintenance of pregnancy. Biol. Reprod., 66: 642-650.

Enge land M., van den Eijnde S.M., A ken T., Vermeij-Keers C., R a maekers F.C., $\mathrm{S}$ chut te B., Reuteling sperger C.P. (2001). Detection of apoptosis in ovarian cells in vitro and in vivo using the annexin V-affinity assay. Methods Mol. Med., 39: 669-677.

Estaquier J., Idziorek T., Zou W., Emilie D., Farber C.M., Bourez J.M., A meis e n J.C. (1995). T helper type 1/T helper type 2 cytokines and $T$ cell death: preventive effect of interleukin 12 on activation-induced and CD95 (FAS/APO-1)-mediated apoptosis of CD4 ${ }^{+}$cells from human immunodeficiency virus-infected persons. J. Exp. Med., 182: 1759-1767.

Estaquier J., Taneka M., Suda T., Nagata S., Golstein P., Ameisen J.C. (1996). Fas-mediated apoptosis of $\mathrm{CD}^{+}$and $\mathrm{CD}^{+} \mathrm{T}$ cells from human immunodeficiency virus-infected persons: differential in vitro preventive effect of cytokines and protease antagonists. Blood, 87: 4959-4966.

Fad ok V.A., S avill J.S., Has 1 et t D.L., B rat to n G.L., D oherty P.A., C a m pbell P.A., Hen s on P.M. (1992 a). Different populations of macrophages use either the vitronectin receptor or the phosphatidylserine receptor to recognize and remove apoptotic cells. J. Immunol., 149: $4029-4035$. 
F a d ok V.A., Vo elker D.R., Campbell P.A., Cohen J.J., B ratton G.L., Hen son P.M. (1992 b). Exposure of phosphatidylserine on the surface of apoptotic lymphocytes triggers specific recognition and removal by macrophages. J. Immunol., 148: 2207-2216.

F a d o k V.A., L a z l o D.J., N oble P.W., We in s te in L., R i c h e s D.W.H., H e n s on P.M. (1993). Particle digestibility is required for induction of the phosphatidylserine recognition mechanism used by murine macrophages to phagocytose apoptotic cells. J. Immunol., 151: 4274-4285.

Fra s ch S.C., H en s on P.M., N a g a o s K K., F e s s ler M.B., B orre ga ard N., B r a t to n D.L. (2004). Phospholipid flip-flop and phospholipid scramblase 1 (PLSCR1) co-localize to uropod rafts in formylated Met-Leu-Phe-stimulated neutrophils. J. Biol. Chem., 279: 17625-17633.

H y u n S., L e e G., K i m D., K i m H., L e e S., N a m D., J e ong Y., K i m S., Ye o m S., K a n g S., Han J., Lee B., Hwang W. (2003). Production of nuclear transfer-derived piglets using porcine fetal fibroblasts transfected with the enhanced green fluorescent protein. Biol. Reprod., 69: 1060-1068.

Idziorek T., Estaquier J., De B els F., A me is en J.C. (1995). YO-PRO-1 permits cytofluorometric analysis of programmed cell death (apoptosis) without interfering with cell viability. J. Immunol. Methods, 185: 249-258.

J ang G., P ark E.S., Cho J.K., B hu i y a n M.M., L e e B.C., K a ng S.K., H wang W.S. (2004). Preimplantational embryo development and incidence of blastomere apoptosis in bovine somatic cell nuclear transfer embryos reconstructed with long-term cultured donor cells. Theriogenology, 62: 512-521.

Ji ang L., Carter D.B., X u J., Yang X., Prather R.S., Ti a n X.C. (2004). Telomere lengths in cloned transgenic pigs. Biol. Reprod., 70: 1589-1593.

K o o D.-B., K a n g Y.-K., P a r k J.S., P a r k J.-K., C h a ng W.-K., L e e K.-K., H a n Y.-M. (2004). A paucity of structural integrity in cloned porcine blastocysts produced in vitro. Theriogenology, 62: 779-789.

Kues W.A., Carnwarth J.W., Paul D., Ni e mann H. (2002). Cell cycle synchronization of porcine fetal fibroblasts by serum deprivation initiates a nonconventional form of apoptosis. Cloning Stem Cells, 4: 231-243.

L e e J.-W., W u S.-C., T i a n X.C., B a rb e r M., H o a g l a n d T., R i e s e n J., L e e K.-H., T u C.-F., Cheng W.T.K., Yang X. (2003 a). Production of cloned pigs by whole-cell intracytoplasmic microinjection. Biol. Reprod., 69: 995-1001.

Le e G.S., Hyun S.H., Kim H.S., Kim D.Y., Lee S.H., Lim J.M., Lee E.S., Kang S.K., L e e B.C., Hw ang W.S. (2003 b). Improvement of a porcine somatic cell nuclear transfer technique by optimizing donor cell and recipient oocyte preparations. Theriogenology, 59: 1949-1957.

L e e G.S., Kim H.S., Hy un S.H., L e e S.H., J e on H.Y., N a m D.H., J e ong Y.W., K im S., K im J.H., Han J.Y., Ahn C., Kang S.K., Lee B.C., Hwang W.S. (2005). Production of transgenic cloned piglets from genetically transformed fetal fibroblasts selected by green fluorescent protein. Theriogenology, 63: 973-991.

L i n c z L.F. (1998). Deciphering the apoptotic pathway: all roads lead to death. Immunol. Cell Biol., 76: $1-19$.

Martin S.J., Reutelingsperger C.P., McGahon A.J., Rader J.A., van Schie R.C., L a F a c e D.M., Green D.R. (1995). Early redistribution of plasma membrane phosphatidylserine is a general feature of apoptosis regardless of the initiating stimulus: inhibition by overexpression of Bcl-2 and Abl. J. Exp. Med., 182: 1545-1556.

Park K.-W., Lai L., Cheong H.-T., Cabot R., Sun Q.-Y., Wu G., Rucker E.B., Durtschi D., B onk A., Samuel M., Rieke A., Day B.N., Murphy C.N., Carter D.B., Prather R.S. (2002). Mosaic gene expression in nuclear transfer-derived embryos and the production of cloned transgenic pigs from ear-derived fibroblasts. Biol. Reprod., 66: 1001-1005.

R a m s o ond a r J.J., M a chaty Z., Cost a C., Willi a m s B.L., F o d o r W.L., B o n d i oli K.R. (2003). Production of $\alpha 1,3$-galactosyltransferase-knockout cloned pigs expressing human $\alpha 1,2-$ fucosylosyltransferase. Biol. Reprod., 69: 437-445.

S a m i e c M. (2004). Development of pig cloning studies: past, present and future. J. Anim. Feed Sci., 13: $211-238$.

S a m i e c M. (2005 a). The effect of mitochondrial genome on architectural remodeling and epigenetic reprogramming of donor cell nuclei in mammalian nuclear transfer-derived embryos. J. Anim. Feed Sci., 14: 393-422. 
$\mathrm{S}$ a $\mathrm{m}$ i e c M. (2005 b). The role of mitochondrial genome (mtDNA) in somatic and embryo cloning of mammals. J. Anim. Feed Sci., 14: 213-233.

S a m i e c M., S kr z y s z o w s k a M. (2005 a). Microsurgical nuclear transfer by intraooplasmic karyoplast injection as an alternative embryo reconstruction method in somatic cloning of pigs and other mammal species; application value of the method and its technical advantages: a review. Czech J. Anim. Sci., 50: 235-242.

S a m i e c M., S krzy s z o w s k a M. (2005 b). Molecular conditions of the cell nucleus remodelling/ reprogramming process and nuclear-transferred embryo development in the intraooplasmic karyoplast injection technique: a review. Czech J. Anim. Sci., 50: 185-195.

S a mi e c M., Skrzys z ow s k a M. (2010 a). The use of different methods of oocyte activation for generation of porcine fibroblast cell nuclear-transferred embryos. Ann. Anim. Sci., 10: 399-411.

S a mi e c M., S krzyszows ka M. (2010 b). Preimplantation developmental capability of cloned pig embryos derived from different types of nuclear donor somatic cells. Ann. Anim. Sci., 10: 385-398.

S a m i e c M., Skrzyszow s ka M. (2011 a). The possibilities of practical application of transgenic mammalian species generated by somatic cell cloning in pharmacology, veterinary medicine and xenotransplantology. Pol. J. Vet. Sci., 14: 329-340.

S a m i e c M., Skrzy s z ow s k a M. (2011 b). Transgenic mammalian species, generated by somatic cell cloning, in biomedicine, biopharmaceutical industry and human nutrition/dietetics - recent achievements. Pol. J. Vet. Sci., 14: 317-328.

S a m i e c M., Skrzys zow s ka M. (2012 a). Roscovitine is a novel agent that can be used for the activation of porcine oocytes reconstructed with adult cutaneous or fetal fibroblast cell nuclei. Theriogenology, 78: 1855-1867.

S a m i e c M., S k r z y s z o w s k a M. (2012 b). High developmental capability of porcine cloned embryos following trichostatin A-dependent epigenomic transformation during in vitro maturation of oocytes pre-exposed to $R$-roscovitine. Anim. Sci. Pap. Rep., 30: 383-393.

S a m i e c M., S k rzy s z ow s ka M., L i p ińs ki D. (2012). Pseudophysiological transcomplementary activation of reconstructed oocytes as a highly efficient method used for producing nucleartransferred pig embryos originating from transgenic foetal fibroblast cells. Pol. J. Vet. Sci., 15: 509-516.

Samiec M., Skrzyszowska M., S morąg Z. (2003). Effect of activation treatments on the in vitro developmental potential of porcine nuclear transfer embryos. Czech J. Anim. Sci., 48: 499-507.

S c hu e t z A.W., Wh it t in gh a m D.G., S n ow d en R. (1996). Alterations in the cell cycle of mouse cumulus granulosa cells during expansion and mucification in vivo and in vitro. Reprod. Fertil. Dev., 8: 935-943.

Skrzys zow ska M., S a m i e c M. (2005). Production of porcine nuclear transfer embryos using fetal fibroblast cells analyzed on apoptosis. Reprod. Fertil. Dev., 17: 182-183.

Skrzys z ow s ka M., S a m i e c M. (2008). Live plasma membrane analysis of early apoptotic cell death in porcine adult dermal fibroblasts prior to somatic cell cloning. Reprod. Fertil. Dev., 20, p. 108 .

Skrzyszowska M., Karasiewicz J., Bednarczyk M., Samiec M., Smorąg Z., Waś B., Guszkiewicz A., Korwin-Kossakowski M., Górniewska M., Szablisty E., Modliński J.A., Łakota P., Wawrzyńska M., Sechman A., Wojtysiak D., Hrabia A., Mika M., Lisowski M., Czekalski P., Rząsa J., Kapkow $\mathrm{s} \mathrm{k}$ a E. (2006). Generation of cloned and chimeric embryos/offspring using the new methods of animal biotechnology. Reprod. Biol., 6 (Suppl. 1): 119-135.

S krzy s z o w s k a M., S a m i e c M., Sło m s ki R., Li p ińs ki D., Mały E. (2008). Development of porcine transgenic nuclear-transferred embryos derived from fibroblast cells transfected by the novel technique of nucleofection or standard lipofection. Theriogenology, 70: 248-259.

S k r z y s z o w s k a M., S a m i e c M., S m or ą g Z. (2005). The effect of in vitro culture conditions on the developmental potential of porcine nuclear transfer embryos reconstructed with cumulus cells. Ann. Anim. Sci., 5: 99-109.

S krzy s zow s ka M., S a mi e c M., S m orąg Z., Li piński D., Sło m s ki R. (2007). Creation of porcine transgenic nuclear-transferred embryos reconstructed with eGFP-expressing adult dermal fibroblast cells analyzed on apoptosis. Reprod. Fertil. Dev., 19: 160-161. 
Uh m S.J., C hung H.M., K i m C., S h i m H., K i m N.-H., L e e H.T., Ch un g K.S. (2000). In vitro development of porcine enucleated oocytes reconstructed by the transfer of porcine fetal fibroblasts and cumulus cells. Theriogenology, 54: 559-570.

Wakayama T., Perry A.C.F., Zuccotti M., Johnson K.R., Yanagimachi R. (1998). Full-term development of mice from enucleated oocytes injected with cumulus cell nuclei. Nature, 394: 369-374.

Yin X.J., Tani T., Yonemura I., Kawakami M., Miyamoto K., Hasegawa R., K a t o Y., Ts un od a Y. (2002). Production of cloned pigs from adult somatic cells by chemically assisted removal of maternal chromosomes. Biol. Reprod., 67: 442-446.

Accepted for printing 18 II 2013

\title{
MARCIN SAMIEC, MARIA SKRZYSZOWSKA
}

\author{
Ocena zdolności rozwojowych in vitro klonalnych zarodków świni rekonstytuowanych z jąder \\ komórek wzgórka jajonośnego poddawanych przyżyciowej diagnostyce w kierunku wykrywania \\ apoptozy
}

\section{STRESZCZENIE}

Celem niniejszej pracy była dokładna analiza porównawcza pozaustrojowych zdolności rozwojowych klonalnych zarodków świni zrekonstruowanych z jąder komórek wzgórka jajonośnego lub jąder fibroblastów tkanki skórnej dorosłych osobników, które oceniono jako nieapoptotyczne na podstawie przyżyciowej analizy programowanej śmierci komórek z wykorzystaniem fluorescencyjnych markerów YO-PRO-1 lub aneksyny V-eGFP. W grupie I 155/364 (42,6\%) i 54/364 (14,8\%) zarodków klonalnych, które zrekonstytuowane były z jąder nieapoptotycznych i/lub nienekrotycznych (tj. YO-PRO-1-i aneksyno V-eGFP-negatywnych) komórek wzgórka jajonośnego, wykazywało kompetencje rozwojowe do stadium moruli i blastocysty. Z kolei, w grupie II do stadium moruli i blastocysty rozwinęło się, odpowiednio, 207/358 (57,8\%) i 110/358 (30,7\%) zarodków klonalnych, które uzyskane były z nieapoptotycznych i/lub nienekrotycznych fibroblastów tkanki skórnej dorosłych osobników. Mimo że potencjał rozwojowy in vitro klonalnych zarodków świni zrekonstruowanych z jąder nieapoptotycznych/nienekrotycznych komórek wzgórka jajonośnego utrzymywał się na istotnie niższym poziomie niż w przypadku zarodków pochodzących z enukleowanych oocytów, do rekonstrukcji których użyto nieapoptotycznych/nienekrotycznych fibroblastów tkanki skórnej dorosłych osobników $(\mathrm{P}<0.001)$, to jednak okazało się, że odsetek uzyskanych morul i blastocyst znacznie przewyższa wyniki badań opublikowane przez innych autorów. Podsumowując, zgodnie z naszą wiedzą, tak obszerne badania nad przedimplantacyjnymi kompetencjami rozwojowymi klonalnych zarodków świni rekonstytuowanych z jąder komórek somatycznych o różnym rodowodzie (komórek wzgórka jajonośnego lub fibroblastów tkanki skórnej dorosłych osobników), które były przyżyciowo diagnozowane w kierunku braku proapoptotycznych transformacji w ich błonach plazmatycznych, nie były dotąd przeprowadzone. 
